\title{
Should asymptomatic patients discharged with lower hemoglobin expect worse outcomes after valve surgery?
}

\author{
Niv Ad, MD, Sari D. Holmes, PhD, Deborah J. Shuman, BS, Alan M. Speir, MD, Graciela Pritchard, BS, \\ and Linda Halpin, MSN, RN
}

\begin{abstract}
Objective: Blood transfusion in cardiac surgery patients is associated with increased morbidity and cost. The decision to transfuse patients after surgery varies but is often based on low hemoglobin $(\mathrm{Hgb})$ levels, regardless of symptom status. This study examined whether asymptomatic patients discharged with lower Hgb levels had increased risk for perioperative complications and 1-year mortality.
\end{abstract}

Methods: Between 2008 and mid-2014, a total of 1107 valve-only procedures were performed. Patients discharged alive with complete data $(\mathrm{N}=1044)$ were divided into 2 groups with discharge $\mathrm{Hgb}$ levels of $\leq 8 \mathrm{~g} / \mathrm{dL}(\mathrm{n}=153)$ or $>8 \mathrm{~g} /$ $\mathrm{dL}(\mathrm{n}=891)$. Propensity score matching was conducted between Hgb groups, resulting in 152 patient pairs.

Results: In multivariate analyses, discharge $\mathrm{Hgb}$ level did not predict 30-day mortality (odds ratio $[\mathrm{OR}]=1.01, P=.991$ ), 1-year survival (hazard ratio $[\mathrm{HR}]=0.87, P=.34)$, or readmission $<30$ days $(\mathrm{OR}=0.92, P=.31)$. Furthermore, after propensity score matching, no differences were found between groups with Hgb levels $\leq 8$ versus $>8 \mathrm{~g} / \mathrm{dL}$ in 30 -day mortality $(0 \%$ vs $0.7 \%, P>.99)$ or readmissions $(14 \%$ vs $16 \%, P=.52)$. Cumulative 1 -year survival was similar between matched groups with discharge $\mathrm{Hgb}$ level of $\leq 8$ versus $>8 \mathrm{~g} / \mathrm{dL}(89.3 \% \mathrm{vs}$ $91.4 \%, P=.67)$. Matched groups with $\mathrm{Hgb}$ level $\leq 8$ versus $>8 \mathrm{~g} / \mathrm{dL}$ had similar physical (28\% vs $18 \%$ increase; $P=.27)$ and mental $(7 \%$ vs $6 \%$ increase; $P=.94)$ health-related quality of life (HRQL) improvements at 6 months.

Conclusions: Asymptomatic patients discharged with lower Hgb levels did not manifest inferior outcomes, including perioperative morbidity/mortality, readmission $<30$ days, HRQL, and 1-year survival. The practice of blood transfusion to correct lower $\mathrm{Hgb}$ levels in asymptomatic patients should be eliminated, as it may be associated with increased morbidity without apparent clinical benefits after valve surgery. (J Thorac Cardiovasc Surg 2015;150:1322-9)

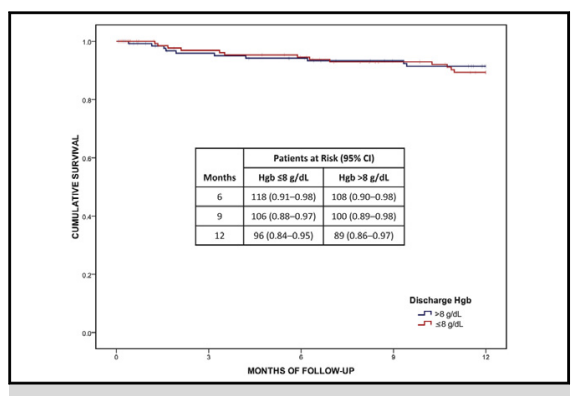

Cumulative survival for propensity score-matched groups, by discharge $\mathrm{Hgb}$ level.

\section{Central Message}

In asymptomatic valve surgery patients, hemoglobin level at discharge was not predictive of early outcomes or 1-year survival.

\section{Perspective}

This study found no association between adverse outcomes and a lower Hgb level at discharge in asymptomatic patients after valve surgery. The practice of blood transfusion after valve surgery to correct lower Hgb levels in asymptomatic patients before discharge should be eliminated, as it may be associated with increased morbidity without apparent clinical benefits.

See Editorial Commentary page 1330.

See Editorial page 1032.
The great majority of transfusions of blood and blood products in the United States are given to cardiac surgery patients. ${ }^{1}$ For many decades, common practice has been to transfuse surgery patients when hemoglobin $(\mathrm{Hgb})$ levels fall to $<10 \mathrm{~g} / \mathrm{dL}$, regardless of whether the patient is

From the Cardiac Surgery Research Department at Inova Heart and Vascular Institute, Falls Church, Va.

Received for publication March 10, 2015; revisions received July 13, 2015; accepted for publication July 17, 2015; available ahead of print Aug 25, 2015.

Address for reprints: Niv Ad, MD, Cardiac Surgery Research, Inova Heart and

Vascular Institute, 3300 Gallows Rd, Ste 3100, Falls Church, VA 22042 (E-mail:

Niv.Ad@inova.org).

$0022-5223 / \$ 36.00$

Copyright (C) 2015 by The American Association for Thoracic Surgery

http://dx.doi.org/10.1016/j.jtcvs.2015.07.076 symptomatic. $^{2}$ This practice is based on evidence that shows an association between anemia and increased morbidity and mortality. ${ }^{3,4}$ Yet with some exceptions, ${ }^{5}$ the preponderance of literature shows transfusion itself to be associated with an increased risk of morbidity and mortality, a longer length of stay, and increased costs. ${ }^{6-9}$

Several associations and organizations have set forth guidelines for perioperative blood transfusion. ${ }^{1,10-12}$ Despite these guidelines, however, actual transfusion practices vary widely both within and among institutions. ${ }^{13-16}$ Moreover, although the most recent blood conservation guidelines from the Society of Thoracic Surgeons (STS) and the Society of Cardiovascular Anesthesiologists are based on an extensive survey of the published literature, those 


\section{Abbreviations and Acronyms \\ $\mathrm{Hgb}=$ hemoglobin \\ $\mathrm{HR}=$ hazard ratio \\ $\mathrm{HRQL}=$ health-related quality of life \\ $\mathrm{OR}=$ odds ratio \\ SF-12 = Medical Outcomes Study Short-Form 12 \\ STS $=$ Society of Thoracic Surgeons}

organizations found almost no evidence to stratify blood conservation interventions. ${ }^{1}$

To date, there is no established, widely recognized no $\mathrm{Hgb}$ threshold below which blood transfusion can be consistently recommended for patients undergoing cardiac surgery. ${ }^{2}$ This threshold is especially important for patients who have lower $\mathrm{Hgb}$ levels well after the intensive phase of their postoperative care, when they are asymptomatic, ambulating very well, and awaiting discharge from the hospital. The purpose of this study was to determine whether lower Hgb levels at discharge in asymptomatic patients who have undergone valve surgery are associated with an increased risk of perioperative complications and 1-year mortality.

\section{METHODS}

All study procedures were performed in accordance with the ethical standards of the responsible committee on human experimentation (institutional and national) and with the Helsinki Declaration of 1975, as revised in 2000. This prospective study was conducted at a single center with a cohort of consecutive patients who underwent valve-only cardiac surgical procedures between April 2008 and June 2014 and were discharged alive from the hospital. During that period, 2551 patients underwent valve surgery, and 1107 valve-only procedures were performed (Figure 1).

All patients included in these analyses $(\mathrm{N}=1044)$ had complete data available on presurgery and discharge $\mathrm{Hgb}$ and on blood transfusion. Blood transfusion was managed in accordance with our rigorous institutional protocol and the STS guidelines. ${ }^{1,17}$ Patients were divided into 2 groups based on discharge Hgb levels: $\leq 8 \mathrm{~g} / \mathrm{dL}(\mathrm{n}=153)$ and $>8 \mathrm{~g} / \mathrm{dL}(\mathrm{n}=891)$. Within the former group, $24(16 \%)$ patients had a discharge $\mathrm{Hgb}$ level of $\leq 7 \mathrm{~g} / \mathrm{dL}$.

The value of $8 \mathrm{~g} / \mathrm{dL}$ was selected for the Hgb cut-point to represent patients with significant anemia, because it additionally represents a strong relationship with blood product transfusion, even in asymptomatic patients. ${ }^{18}$ Asymptomatic patients were defined as clinically stable, ambulating well on the floor, and maintaining normal blood pressure with no orthostatic hypotension, dizziness, tachycardia, tachypnea, or shortness of breath. These factors were evaluated daily as part of our institutional clinical protocol.

Data were collected prospectively using our local STS database and institutional cardiac surgery database. Outcome measures included STSdefined morbidity, readmissions within 30 days, postdischarge mortality within 30 days of surgery, mortality during the first year of follow-up, and health-related quality of life (HRQL) using the Medical Outcomes Study Short Form-12 (SF-12) before surgery and at the 6-month follow-up after surgery. This study was approved by our local institutional review board (IRB nos. 06.022 and 12.055). Patient consent was waived for our registry.

\section{Statistical Analysis}

All analyses were performed with SPSS Version 17.0 (SPSS Inc, Chicago, Ill) or R 2.10.1 (R Foundation for Statistical Computing, Vienna,
Austria), and a 2 -sided $P$ value $<.05$ was used to determine significance Continuous data are presented as mean $\pm \mathrm{SD}$, or median (interquartile range); categorical data are presented as frequency (percentage), unless otherwise noted. Comparisons of the discharge Hgb groups were conducted using independent-samples $t$ tests or the Mann-Whitney $U$ test for continuous variables, and $\chi^{2}$ analysis or the Fisher exact test for categorical variables.

Outcome analyses were first conducted in the unmatched full sample to evaluate the relationship of discharge $\mathrm{Hgb}$ level as a continuous variable to the primary outcomes, including 30-day postdischarge mortality and 1year survival, as well as discharge location and readmission within 30 days after discharge. These analyses were conducted using multivariate logistic and Cox regressions with the following covariates: age, gender, body mass index, chronic pulmonary disease, diabetes, ejection fraction, cerebrovascular disease, preoperative Hgb level, year of surgery, cardiopulmonary bypass time, and receipt of blood products during surgical hospitalization. Box-Tidwell testing revealed that the interaction term of discharge $\mathrm{Hgb}$ with the natural log of discharge $\mathrm{Hgb}$ level was not significant in any of the logistic regression analyses.

As a second step, propensity score matching was conducted to improve clinical covariate balance between the discharge Hgb groups, using the MatchIt package within R. ${ }^{19-21}$ Propensity scores were estimated via a logistic model that examined discharge $\mathrm{Hgb}$ group as the dependent variable and the following independent variables selected a priori: age, gender, chronic pulmonary disease, diabetes, ejection fraction, cerebrovascular disease, preoperative $\mathrm{Hgb}$ level, year of surgery, cardiopulmonary bypass time (minutes), and blood product transfusion during the surgical hospitalization.

Patients with a discharge $\mathrm{Hgb}$ level of $\leq 8 \mathrm{~g} / \mathrm{dL}$ were matched to patients with a discharge $\mathrm{Hgb}$ level of $>8 \mathrm{~g} / \mathrm{dL}$, using propensity scores and a caliper of 0.25 propensity score SD. ${ }^{19}$ After matching, balance was improved for all covariates in the logistic model (Table 1), and almost all patients with a discharge $\mathrm{Hgb}$ level of $\leq 8 \mathrm{~g} / \mathrm{dL}$ were able to be matched (Figure 2). A total of 152 pairs of patients remained after propensity score matching $(\mathrm{N}=304)$, and this sample was used in analyses where noted.

Outcome analyses on the propensity score-matched sample $(\mathrm{N}=304)$ utilized independent-samples $t$ tests or Mann-Whitney $U$ tests for continuous variables, and $\chi^{2}$ analysis or the Fisher exact test for categorical variables. Kaplan-Meier survival analysis was used to compare the discharge $\mathrm{Hgb}$ groups on 1-year survival. Changes in HRQL between Hgb groups were examined using repeated measures ANOVA.

\section{RESULTS \\ Patients}

The mean age of patients in this sample $(\mathrm{N}=1044)$ was $62.1 \pm 14.0$ years, and $37 \%$ were women. The sample collectively underwent 918 single-valve, 114 double-valve, and 12 triple-valve surgeries. The breakdown of which valve types were involved in these operations is: 514 mitral, 593 aortic, 72 tricuspid, and 3 pulmonary. Given that some patients had surgeries on multiple valves simultaneously, these numbers are not mutually exclusive. The mean $\mathrm{Hgb}$ level at discharge was $9.9 \pm 1.7 \mathrm{~g} / \mathrm{dL}$; the distribution of discharge $\mathrm{Hgb}$ level is shown in Figure 3. Before matching, patients with a discharge $\mathrm{Hgb}$ level of $\leq 8 \mathrm{~g} / \mathrm{dL}$ differed from patients with a discharge $\mathrm{Hgb}$ level of $>8 \mathrm{~g} / \mathrm{dL}$ in preoperative and intraoperative characteristics (Table 2).

In particular, patients with discharge $\mathrm{Hgb}$ level of $\leq 8 \mathrm{~g} /$ $\mathrm{dL}$ were more likely to be women ( $44 \%$ vs $36 \%, P=.041)$ and to have cerebrovascular disease $(23 \%$ vs $11 \%$, 


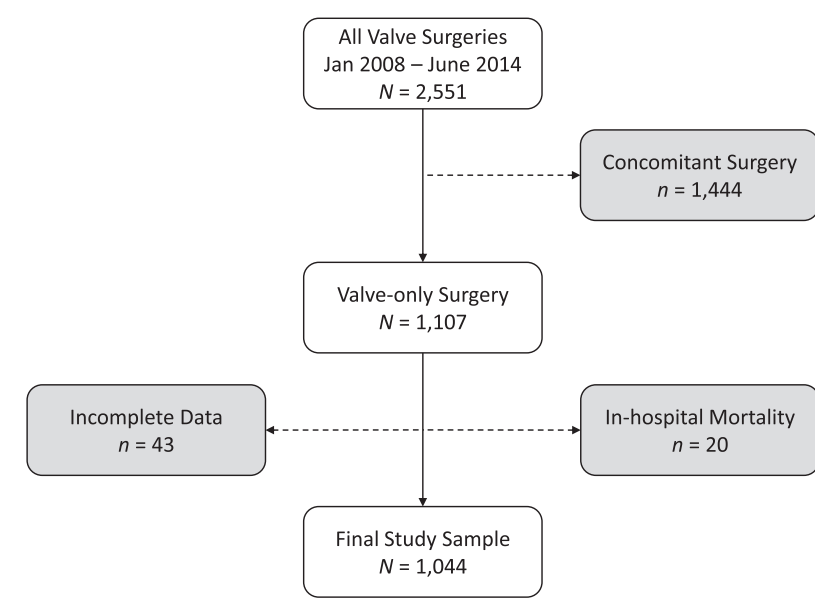

FIGURE 1. Flowchart illustrating inclusion criteria for the study sample.

$P<.001)$. Patients with a discharge Hgb level of $\leq 8 \mathrm{~g} / \mathrm{dL}$ were, additionally, less likely to have had an elective valve surgery $(78 \%$ vs $89 \%, P<.001)$ and a single-valve procedure $(76 \%$ vs $90 \%, P<.001)$. Patients with a discharge $\mathrm{Hgb}$ level of $\leq 8 \mathrm{~g} / \mathrm{dL}$ had lower mean preoperative $\mathrm{Hgb}$ levels $(11.3$ vs $13.1 \mathrm{~g} / \mathrm{dL}, P<.001)$ and longer mean cardiopulmonary bypass time ( 135 vs 123 minutes, $P=.010$ ). After matching, the 2 groups were balanced on all preoperative and intraoperative characteristics, particularly those included in the propensity score model (Table 3 ).

\section{Multivariate Analyses With Discharge Hemoglobin}

Discharge $\mathrm{Hgb}$ as a continuous variable was not predictive of incidence of postdischarge mortality within 30 days (odds ratio $[\mathrm{OR}]=1.01,95 \%$ confidence interval $[\mathrm{CI}]=0.45-2.25, \quad P=.991)$, discharge to home $(\mathrm{OR}=1.06,95 \% \mathrm{CI}=0.89-1.25, P=.542)$, or readmission within 30 days $(\mathrm{OR}=0.92,95 \% \mathrm{CI}=0.78-1.08$, $P=.313$ ) in the entire sample, after adjustment for clinical covariates, as described earlier. Similarly, discharge $\mathrm{Hgb}$ as a continuous variable was not related to 1-year survival

TABLE 1. Covariate balance achieved from propensity scorematching technique

\begin{tabular}{lccc}
\hline \multicolumn{1}{c}{ Characteristic } & $\begin{array}{c}\text { Std diff } \\
\text { Before PSM }\end{array}$ & $\begin{array}{c}\text { Std diff } \\
\text { After PSM }\end{array}$ & $\begin{array}{c}\text { Percentage } \\
\text { Improvement }\end{array}$ \\
\hline Age (y) & 0.008 & -0.001 & 89 \\
Female & 0.173 & -0.026 & 85 \\
Chronic pulmonary disease & 0.246 & 0.029 & 88 \\
Diabetes mellitus & 0.295 & 0.044 & 85 \\
Ejection fraction (\%) & 0.062 & 0.001 & 99 \\
Cerebrovascular disease & 0.274 & 0.062 & 77 \\
Preoperative Hgb (g/dL) & -1.007 & -0.054 & 95 \\
Cardiopulmonary bypass & 0.224 & 0.047 & 79 \\
$\quad$ time (min) & & & \\
Blood product transfusion & 0.562 & 0.000 & 100 \\
Year of surgery & 0.041 & -0.032 & 22 \\
\hline
\end{tabular}

Std diff, Standard difference; PSM, propensity score matching; $\mathrm{Hg}$, hemoglobin.

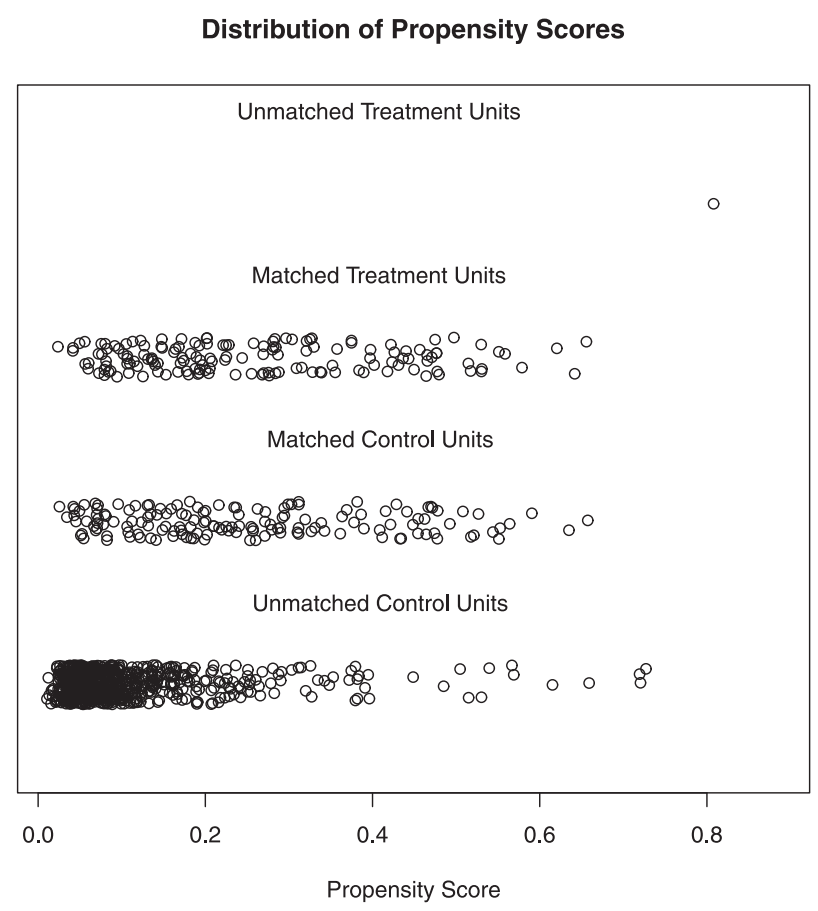

FIGURE 2. Distribution of propensity scores for control (discharge Hgb level $>8 \mathrm{~g} / \mathrm{dL}$ ) and treatment (discharge Hgb level $\leq 8 \mathrm{~g} / \mathrm{dL}$ ) units.

(hazard ratio $[\mathrm{HR}]=0.87,95 \% \mathrm{CI}=0.65-1.16$, $P=.344)$ after multivariate adjustment.

\section{Propensity Score-Matched Outcome Analyses}

During the postoperative course, patients who were discharged with an Hgb level of $\leq 8$ or $>8 \mathrm{~g} / \mathrm{dL}$ did not differ in the incidence of reoperations for bleeding ( $3 \%$ vs $5 \%$, $P=.357)$, prolonged ventilation $>24$ hours $(15 \%$ vs $16 \%, P=.874)$, pneumonia ( $4 \%$ vs $5 \%, P=.584)$, stroke/transient ischemic attack ( $1 \%$ vs $1 \%, P>.999)$, or

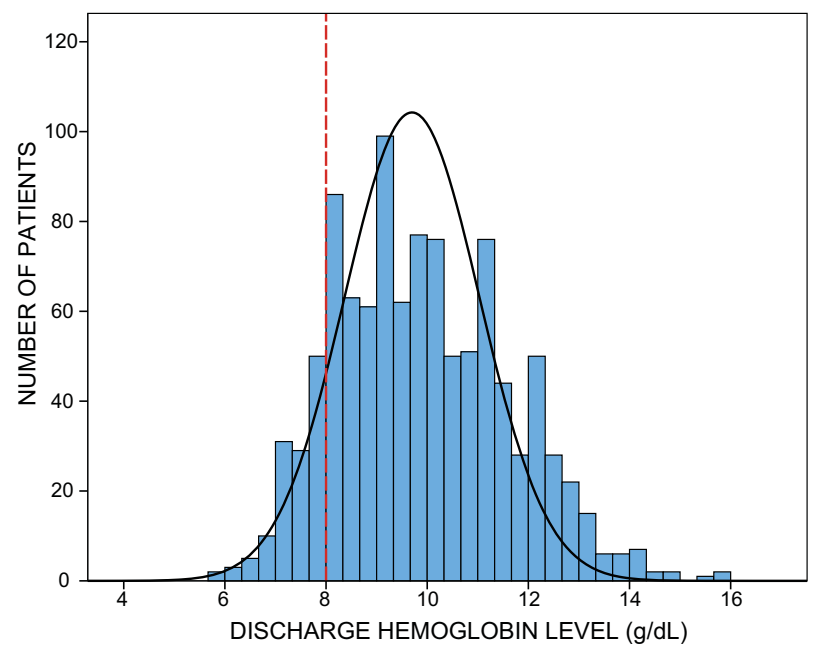

FIGURE 3. Histogram illustrating the distribution of Hgb levels at discharge within the entire sample. 
TABLE 2. Patient characteristics before propensity score matching

\begin{tabular}{|c|c|c|c|}
\hline Characteristic & $\begin{array}{c}\mathrm{Hgb}>8 \mathrm{~g} / \mathrm{dL} \\
(\mathrm{n}=891)\end{array}$ & $\begin{array}{c}\mathbf{H g b} \leq \mathbf{8} \text { g/dL } \\
(\mathrm{n}=\mathbf{1 5 3})\end{array}$ & $P$ value \\
\hline Age & $62.0 \pm 13.8$ & $62.2 \pm 15.1$ & .924 \\
\hline Female & $319(36)$ & $68(44)$ & .041 \\
\hline Diabetes mellitus & $132(15)$ & $43(28)$ & $<.001$ \\
\hline Body mass index $\left(\mathrm{kg} / \mathrm{m}^{2}\right)$ & $28.0 \pm 6.2$ & $28.2 \pm 5.8$ & .728 \\
\hline Hypertension & $527(59)$ & $104(68)$ & .039 \\
\hline Congestive heart failure & $260(29)$ & $68(44)$ & $<.001$ \\
\hline Ejection fraction $(\%)$ & $57.7 \pm 10.4$ & $58.3 \pm 9.6$ & .507 \\
\hline $\begin{array}{l}\text { Previous cerebrovascular } \\
\text { accident }\end{array}$ & $63(7)$ & $20(13)$ & .011 \\
\hline Cerebrovascular disease & $101(11)$ & $35(23)$ & $<.001$ \\
\hline Chronic pulmonary disease & $162(18)$ & $45(29)$ & .001 \\
\hline Creatinine $>2 \mathrm{mg} / \mathrm{dL}$ & $34(4)$ & $15(10)$ & .001 \\
\hline Peripheral vascular disease & $51(6)$ & $13(9)$ & .187 \\
\hline Preoperative Hgb $(\mathrm{g} / \mathrm{dL})$ & $13.1 \pm 1.9$ & $11.3 \pm 1.8$ & $<.001$ \\
\hline STS mortality risk (\%) & $1.9 \pm 2.6$ & $3.8 \pm 6.1$ & .001 \\
\hline EuroSCORE II (\%) & $2.8 \pm 4.9$ & $6.0 \pm 9.3$ & $<.001$ \\
\hline Elective status & $793(89)$ & $119(78)$ & $<.001$ \\
\hline Single valve procedure & $802(90)$ & $116(76)$ & $<.001$ \\
\hline \multicolumn{4}{|l|}{ Type of surgery } \\
\hline Aortic valve & $495(56)$ & $98(64)$ & .050 \\
\hline Mitral valve & $444(50)$ & $70(46)$ & .351 \\
\hline Tricuspid valve & $48(5)$ & $24(16)$ & $<.001$ \\
\hline Pulmonary valve & $2(0.2)$ & $1(0.7)$ & .379 \\
\hline $\begin{array}{l}\text { Cardiopulmonary bypass } \\
\text { time (min) }\end{array}$ & $123 \pm 44$ & $135 \pm 53$ & .010 \\
\hline Length of stay (d) & $4(3-6)$ & $6(4-11)$ & .002 \\
\hline
\end{tabular}

Data are presented as frequency (\%), median (interquartile range), or mean \pm SD. For the "type of surgery" category, values are not mutually exclusive because some patients had surgery on $>1$ valve. $\mathrm{Hg}$, Hemoglobin; STS, Society of Thoracic Surgeons; EuroSCORE, European System for Cardiac Operative Risk Evaluation.

renal failure ( $3 \%$ vs $1 \%, P=.448)$. The mean discharge $\mathrm{Hgb}$ level was $7.5 \pm 0.5 \mathrm{~g} / \mathrm{dL}$ in the group with an Hgb level of $\leq 8 \mathrm{~g} / \mathrm{dL}$, and $9.6 \pm 1.2$ in the group with an Hgb level of $>8 \mathrm{~g} / \mathrm{dL}(P<.001)$. The matched groups of Hgb level $\leq 8$ and $>8 \mathrm{~g} / \mathrm{dL}$ were not different on the primary outcomes of postdischarge 30-day mortality $(0 \%$ vs $0.7 \%$, $P>.999)$, incidence of readmission $(14 \%$ vs $16 \%$, $P=.522)$, or mortality within 1 year $(9 \%$ vs $7 \%$, $P=.515)$. The primary indications for readmissions in patients with an Hgb level of $\leq 8 \mathrm{~g} / \mathrm{dL}$ were any effusions ( 7 of 21 ), tachyarrhythmias, or bradyarrhythmias (6 of 21), and fluid overload ( 3 of 21).

In patients with an $\mathrm{Hgb}$ level of $>8 \mathrm{~g} / \mathrm{dL}$, the primary indications for readmissions were any effusions (6 of 25), and tachyarrhythmias or bradyarrhythmias (5 of 25). The mode of discharge disposition to home did not differ between matched patients discharged with an Hgb level of $\leq 8$ or $>8 \mathrm{~g} / \mathrm{dL}(81 \%$ vs $80 \%, P=.667)$. Kaplan-Meier analysis found that cumulative 1-year survival was similar between matched patients discharged with an Hgb level of $\leq 8 \mathrm{~g} / \mathrm{dL}$ or $>8 \mathrm{~g} / \mathrm{dL}(89.3 \%$ vs $91.4 \%, \log$ rank $=0.19, P=.67$; Figure 4).
TABLE 3. Patient characteristics after propensity score matching

\begin{tabular}{|c|c|c|c|}
\hline Characteristic & $\begin{aligned} \mathbf{H g b} & >8 \mathrm{~g} / \mathrm{dL} \\
(\mathrm{n} & =152)\end{aligned}$ & $\begin{aligned} \mathbf{H g b} & \leq \mathbf{8} \text { g/dL } \\
(\mathrm{n} & =\mathbf{1 5 2})\end{aligned}$ & $P$ value \\
\hline Age (y) & $62.1 \pm 14.2$ & $62.1 \pm 15.1$ & .994 \\
\hline Female & $70(46)$ & $68(45)$ & .818 \\
\hline Diabetes mellitus & $40(26)$ & $43(28)$ & .699 \\
\hline Body mass index $\left(\mathrm{kg} / \mathrm{m}^{2}\right)$ & $28.4 \pm 7.1$ & $28.3 \pm 5.8$ & .808 \\
\hline Hypertension & $102(67)$ & $103(68)$ & .903 \\
\hline Congestive heart failure & $65(43)$ & $68(45)$ & .729 \\
\hline Ejection fraction $(\%)$ & $58.2 \pm 9.6$ & $58.2 \pm 9.7$ & .994 \\
\hline $\begin{array}{l}\text { Previous cerebrovascular } \\
\text { accident }\end{array}$ & $17(11)$ & $19(13)$ & .723 \\
\hline Cerebrovascular disease & $30(20)$ & $34(22)$ & .574 \\
\hline Chronic pulmonary disease & $42(28)$ & $44(29)$ & .799 \\
\hline Creatinine $>2 \mathrm{mg} / \mathrm{dL}$ & $17(11)$ & $15(10)$ & .709 \\
\hline Peripheral vascular disease & $15(10)$ & $13(9)$ & 692 \\
\hline Preoperative $\mathrm{Hgb}$ (g/dL) & $11.4 \pm 2.0$ & $11.3 \pm 1.8$ & .651 \\
\hline STS mortality risk (\%) & $2.9 \pm 3.4$ & $3.8 \pm 6.1$ & .140 \\
\hline EuroSCORE II (\%) & $4.3 \pm 6.0$ & $6.0 \pm 9.3$ & .063 \\
\hline Elective status & $118(78)$ & $118(78)$ & $>.999$ \\
\hline Single valve procedure & $120(79)$ & $116(76)$ & .582 \\
\hline \multicolumn{4}{|l|}{ Type of surgery } \\
\hline Aortic valve & $86(57)$ & $98(65)$ & .159 \\
\hline Mitral valve & $84(55)$ & $69(45)$ & .085 \\
\hline Tricuspid valve & $17(11)$ & $23(15)$ & .309 \\
\hline Pulmonary valve & 0 & $1(0.7)$ & $>.999$ \\
\hline $\begin{array}{l}\text { Cardiopulmonary bypass time } \\
\text { (min) }\end{array}$ & $131 \pm 53$ & $134 \pm 52$ & .680 \\
\hline Length of stay (d) & $6(4-10.75)$ & $6(4-11)$ & .115 \\
\hline
\end{tabular}

Data are presented as frequency ( $\%)$, median (interquartile range), or mean $\pm \mathrm{SD}$. For the "type of surgery" category, values are not mutually exclusive because some patients had surgery on $>1$ valve. $\mathrm{Hg} b$, Hemoglobin; STS, Society of Thoracic Surgeons; EuroSCORE, European System for Cardiac Operative Risk Evaluation.

\section{Health-Related Quality-of-Life Analyses}

In the subset of matched patients who completed HRQL measures before surgery and at 6 months after surgery

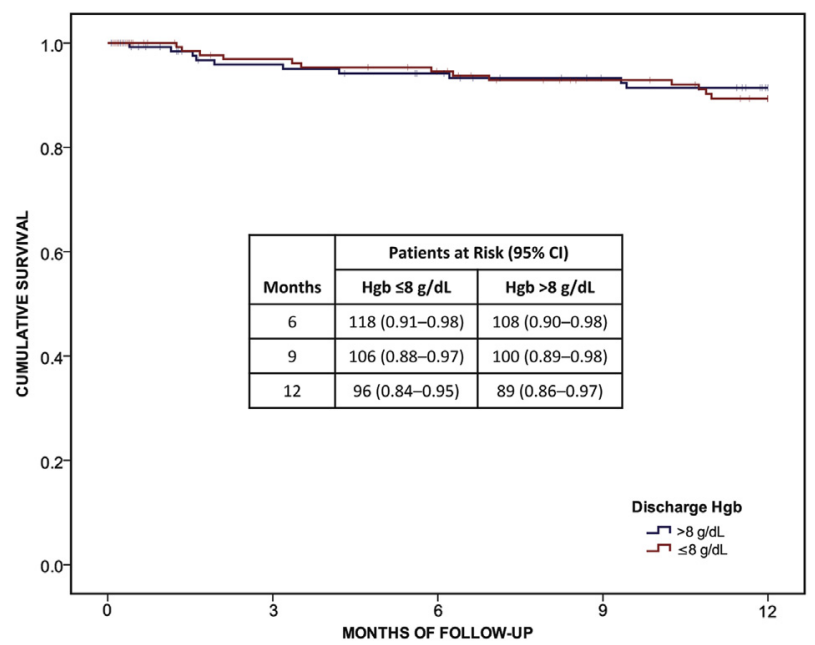

FIGURE 4. Cumulative survival for groups matched on their discharge Hgb levels. $H g b$, Hemoglobin; $C I$, confidence interval. 


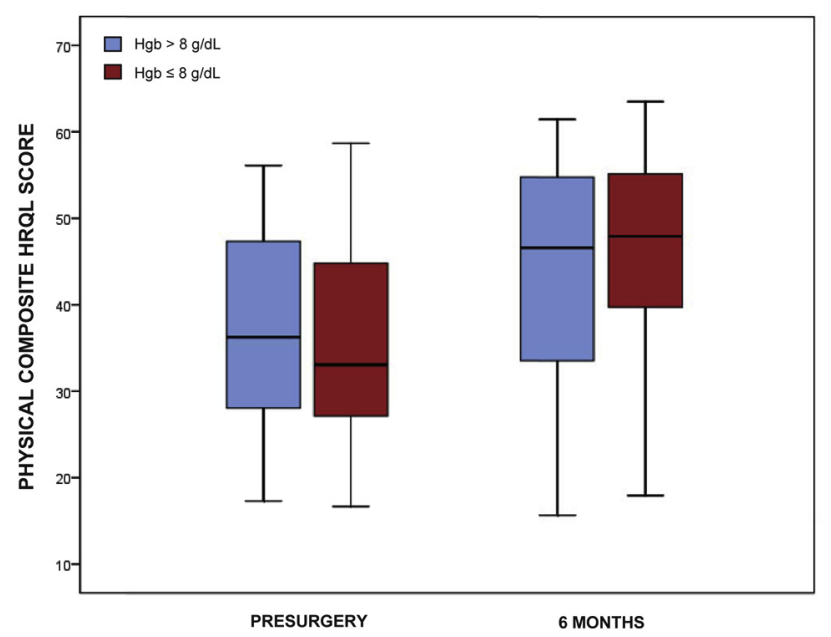

FIGURE 5. Box plots illustrating HRQL improvement in the physical composite scale from the SF-12 from before surgery to 6 months after surgery by groups matched on their discharge Hgb levels. HRQL, Healthrelated quality of life; $\mathrm{Hg} b$, hemoglobin.

$(\mathrm{n}=78)$, a significant improvement was found in the physical composite score $(\mathrm{F}=31.1, P<.001)$, mental composite score $(\mathrm{F}=5.4, P=.023)$, and the general health subscale from the SF-12 $(\mathrm{F}=28.8, P<.001)$. The matched $\mathrm{Hgb}$ $\leq 8$ and $>8 \mathrm{~g} / \mathrm{dL}$ groups had similar improvements in physical composite score (a $28 \%$ vs $18 \%$ increase; $\mathrm{F}=1.25$, $P=.268$; Figure 5) and mental composite score (a $7 \%$ vs $6 \%$ increase; $\mathrm{F}=0.01, P=.943$ ) from before to 6 months after surgery. Although lower general health scores were reported before surgery in the group with $\mathrm{Hgb}$ level $\leq 8 \mathrm{~g} / \mathrm{dL}$, those patients reported similar general health scores at the 6 -month time point after surgery (48.9 vs $47.7, t=-0.6$, $P=.569)$.

\section{Effect of Blood Product Transfusion}

The transfusion rate for the entire sample $(\mathrm{N}=1044)$ was $22 \%$. Patients with a discharge Hgb level of $\leq 8 \mathrm{~g} / \mathrm{dL}$ had a higher incidence of transfusion during their hospital course $(46 \%)$ than the entire sample. As a result of the propensity score matching process, which included transfusion as a covariate, matched patients with a discharge Hgb level of $>8 \mathrm{~g} / \mathrm{dL}$ were identical to patients with a discharge $\mathrm{Hgb}$ level of $\leq 8 \mathrm{~g} / \mathrm{dL}$ in the incidence of any blood product transfusion during the hospital course $(46 \%$ vs $46 \%$, $P>$.999).

In general, patients with a discharge Hgb level of $\leq 8 \mathrm{~g} /$ $\mathrm{dL}$ were sicker (Table 2 ), and the propensity score matching technique resulted in a group of comparable patients (including in transfusion rate) who had a discharge $\mathrm{Hgb}$ level of $>8 \mathrm{~g} / \mathrm{dL}$. When the analyses were separated by time at which blood products were given, no differences remained between matched patients with a discharge $\mathrm{Hgb}$ level of $\leq 8$ and $>8 \mathrm{~g} / \mathrm{dL}$ in intraoperative blood product transfusion $(28 \%$ vs $34 \%, P=.215)$ and postoperative blood product transfusion ( $29 \%$ vs $34 \%, P=.324)$.

Secondary analyses examined the independent effect of blood product transfusion on outcomes, first in multivariate analyses with the entire sample, then in the propensity score-matched sample. In contrast to the discharge Hgb results, multivariate Cox regression analysis found that blood product transfusion was in fact a significant predictor of poorer 1-year survival $(\mathrm{HR}=2.27,95 \% \mathrm{CI}=1.06-4.88$, $P=.036)$, but it was not related to readmissions within 30 days $(\mathrm{OR}=1.51,95 \% \mathrm{CI}=0.75-3.04, P=.244)$.

In the sample that was propensity score matched on discharge Hgb level $(\mathrm{N}=304)$, patients with transfusions did not differ from patients without transfusions in 30-day mortality $(0.7 \%$ vs $0 \%$, respectively, $P=.461)$ or readmissions ( $17 \%$ vs $13 \%$, respectively, $P=.366)$. Discharge to home was less likely for patients with transfusion than for patients without transfusions (69\% vs $89 \%$, respectively, $P<.001)$. Last, 1 -year cumulative survival was significantly worse for patients with transfusions than for patients without transfusions $(85.7 \%$ vs $94.8 \%$, respectively; $\log$ rank $=6.27, P=.012$ ). The negative effect of blood transfusion on 1-year survival remained significant after adjustment for discharge $\mathrm{Hgb}$ level as a continuous variable $(\mathrm{HR}=3.00,95 \% \mathrm{CI}=1.18-7.60, P=.021)$.

\section{DISCUSSION}

In this study of patients who underwent valve surgery at our institution, asymptomatic patients discharged with a low Hgb level $(\leq 8 \mathrm{~g} / \mathrm{dL})$ had outcomes that were comparable to those of patients discharged with an Hgb level $>8 \mathrm{~g} /$ $\mathrm{dL}$; these outcomes include similar survival at 30 days and 1 year, similar readmission rate, and similar improvements in HRQL. On the other hand, blood and blood product transfusion during hospital course was associated with poorer 1year cumulative survival.

Blood transfusion is most often given to cardiac surgery patients to address anemia. ${ }^{2}$ Preoperative anemia is well known to confer increased risks after cardiac surgery. ${ }^{22,23}$ The association of transfusion itself with postoperative adverse outcomes has been widely reported. ${ }^{24-27}$ Conversely, blood conservation protocols were shown to be associated with improved surgical outcomes across a region ${ }^{28}$ in a study based on our institutional blood transfusion protocol, which has been in place since 2007; its success has led to regional implementation. Under our transfusion management protocol, $<20 \%$ of our valve patients receive intraoperative or postoperative blood transfusion, and asymptomatic patients with $\mathrm{Hgb}$ levels of $<8 \mathrm{~g} / \mathrm{dL}$ are discharged with appropriate iron and/or other supplements.

Several reports support the use of a more restrictive strategy for transfusion (ie, at lower Hgb levels). ${ }^{6,17,29,30}$ The transfusion requirements in the septic shock trial ${ }^{31}$ found 
no significant differences in 90-day mortality, severe adverse reactions, use of life support, or survival after discharge between 2 groups of patients who received blood transfusion at $\mathrm{Hgb}$ thresholds of $\leq 7$ and $\leq 9 \mathrm{~g} / \mathrm{dL}$. In another study $^{29}$ evaluating transfusion thresholds, no differences were found in morbidity, mortality, or self-assessed fatigue or anemia with the use of $\mathrm{Hgb}$ thresholds of $<8$ and $<9 \mathrm{~g} /$ dL. In the Transfusion Requirements in Critical Care study, maintenance of $\mathrm{Hgb}$ at 7 to $9 \mathrm{~g} / \mathrm{dL}$, and a transfusion threshold of as low as $7 \mathrm{~g} / \mathrm{dL}$, was not inferior to a more liberal transfusion threshold of $10 \mathrm{~g} / \mathrm{dL}$ and a maintenance range of 10 to $12 \mathrm{~g} / \mathrm{dL}$. $^{32}$

Despite what has been shown in these studies, , $^{6,17,29,30,32}$ the variation in transfusion incidence across US health care facilities reflects the evidence gap in the literature with regard to best practices for blood transfusion., ${ }^{2,18}$ The discrepancy between guideline recommendations and actual practice is exacerbated in part by studies such as the recent report by Murphy and colleagues, ${ }^{5}$ which found that a restrictive transfusion threshold after cardiac surgery was not superior to a liberal threshold with respect to morbidity or health care costs. That single prospective randomized study, however, stands in contrast to an abundance of studies ${ }^{6,8,9,24-27,33,34}$ conducted during the past decadeincluding one by Murphy and colleagues themselves ${ }^{7}$ showing an association between transfusion and an increased risk of complications, adverse outcomes, and cost as well as those $\mathrm{e}^{2,28,29,31,35}$ demonstrating the benefits of blood conservation strategies.

In this study, $153(15 \%)$ patients were discharged with an $\mathrm{Hgb}$ level of $\leq 8 \mathrm{~g} / \mathrm{dL}$. Although the vast majority of patients in our center are discharged with Hgb levels of $>8 \mathrm{~g} / \mathrm{dL}$ (Figure 3), our results were achieved in a significant subgroup of asymptomatic patients who were discharged with lower Hgb levels and had comparable early outcomes and 1 -year survival rates. The results of our study add to the body of evidence showing that, in considering perioperative transfusion strategies to correct anemia in asymptomatic patients, a restrictive $\mathrm{Hgb}$ threshold is not associated with compromised outcomes and may have a positive impact on 30-day results and 1-year survival for patients after valve surgery.

\section{Limitations}

Our study has several limitations that should be taken into account. The results are in agreement with the bulk of the literature in this area. However, they do require validation in a larger patient sample because our results were obtained in a single center with a rigorous multidisciplinary transfusion protocol and thus may not be generalizable to other centers. In addition, the transfusion rate in our propensity score-matched sample was higher than our usual institutional rate, owing to the fact that the analysis was performed on subgroups. However, the transfusion rate in the full sample of this study $(\mathrm{N}=1044)$ was $22 \%$, which is in line with the rate found for our entire population of valve patients.

In addition, although $>1000$ patients were included in the entire study sample, patients discharged with $\mathrm{Hgb}$ levels of $\leq 8 \mathrm{~g} / \mathrm{dL}$ represented only $15 \%$ of the sample. The propensity score-matched analyses may therefore have been affected by this relatively small sample size, which further highlights the need for validation of these findings in a larger sample. Finally, because patients were not prospectively randomized to discharge Hgb groups, unmeasured factors may have confounded our results. However, the propensity score-matching methodology was included as a means to replicate the random occurrence of confounders that would be present in randomized studies. Although the results of the propensity score-matched analyses were in agreement with the unmatched analyses of the entire cohort, future studies utilizing a randomized controlled design are warranted to evaluate the association between discharge $\mathrm{Hgb}$ levels and outcomes in asymptomatic patients.

\section{CONCLUSIONS}

The ongoing challenge in treating anemic patients after cardiac surgery is multifactorial and can present difficulties in making treatment decisions for individual patients. Based on our experience with thousands of patients, however, we believe that an important element in meeting this challenge is to change the culture around transfusion. Implementation of blood conservation protocols has been clearly associated with improved outcomes and cost savings. ${ }^{28,35,36}$ The important message of our study lies in the demonstration that adverse outcomes are not associated with lower $\mathrm{Hgb}$ level at discharge in asymptomatic patients, for all age groups.

A more conservative approach to transfusion is often challenged by physicians accustomed to transfusion, owing to old habits and a belief that any risks associated with transfusion are outweighed by the greater risk of postoperative anemia and the inferior outcomes with which it is associated. The results of this study demonstrate that asymptomatic patients with a lower Hgb level can be safely discharged from the hospital after valve surgery, and that blood transfusion, rather than lower Hgb level at discharge, represents the greater risk of inferior outcomes. The hope is that this study will serve as a model for a prospective randomized study in a larger group of patients to clarify and answer additional clinical questions.

\section{Conflict of Interest Statement}

Niv Ad, MD, is a consultant and a member of the speaker's bureau for Medtronic, Inc, and AtriCure. Alan M. Speir, $\mathrm{MD}$, is on the Medtronic, Inc, advisory board. All other 
authors have nothing to disclose regarding commercial support.

You can watch a Webcast of this AATS meeting presentation by going to: http://webcast.aats.org/2015/Video/ Tuesday/04-28-15_4E_0945_Ad.mp4

\section{References}

1. Society of Thoracic Surgeons Blood Conservation Guideline Task Force, Ferraris VA, Brown JR, Despotis GJ, Hammon JW, Reece TB, et al. 2011 update to the Society of Thoracic Surgeons and the Society of Cardiovascular Anesthesiologists Blood Conservation Clinical Practice Guidelines. Ann Thorac Surg. 2011;91:944-82.

2. Hajjar LA, Vincent JL, Galas FR, Nakamura RE, Silva CM, Santos MH, et al. Transfusion requirements after cardiac surgery: the TRACS randomized controlled trial. JAMA. 2010;304:1559-67.

3. Carson JL, Duff A, Poses RM, Berlin JA, Spence RK, Trout R, et al. Effect of anaemia and cardiovascular disease on surgical mortality and morbidity. Lancet. 1996;348:1055-60.

4. DeFoe GR, Ross CS, Olmstead EM, Surgenor SD, Fillinger MP, Groom RC, et al. Lowest hematocrit on bypass and adverse outcomes associated with coronary artery bypass grafting. Northern New England Cardiovascular Disease Study Group. Ann Thorac Surg. 2001;71:769-76.

5. Murphy GJ, Pike K, Rogers CA, Wordsworth S, Stokes EA, Angelini GD, et al. Liberal or restrictive transfusion after cardiac surgery. N Engl J Med. 2015;372: 997-1008.

6. Horvath KA, Acker MA, Chang H, Bagiella E, Smith PK, Iribarne A, et al. Blood transfusion and infection after cardiac surgery. Ann Thorac Surg. 2013;95:2194-201.

7. Murphy GJ, Reeves BC, Rogers CA, Rizvi SI, Culliford L, Angelini GD. Increased mortality, postoperative morbidity, and cost after red blood cell transfusion in patients having cardiac surgery. Circulation. 2007;116:2544-52.

8. Galas FR, Almeida JP, Fukushima JT, Osawa EA, Nakamura RE, Silva CM, et al. Blood transfusion in cardiac surgery is a risk factor for increased hospital length of stay in adult patients. J Cardiothorac Surg. 2013;8:54.

9. Bhaskar B, Dulhunty J, Mullany DV, Fraser JF. Impact of blood product transfusion on short and long-term survival after cardiac surgery: more evidence. Ann Thorac Surg. 2012;94:460-7.

10. American College of Anesthesiologists. Practice guidelines for blood component therapy: a report by the American Society of Anesthesiologists Task Force on Blood Component Therapy. Anesthesiology. 1996;84:732-47.

11. National Institutes of Health. Perioperative red cell transfusion. National Institutes of Health Consensus Development Conference. Transfus Med Rev. 1989; 3:63-8.

12. Canadian Medical Association. Guidelines for red blood cell and plasma transfusion for adults and children. Can Med Assoc J. 1997;156(Suppl 11):S1-25.

13. Stover EP, Siegel LC, Parks R, Levin J, Body SC, Maddi R, et al. Variability in transfusion practice for coronary artery bypass surgery persists despite national consensus guidelines: a 24-institution study. Institutions of the Multicenter Study of Perioperative Ischemia Research Group. Anesthesiology. 1998;88:327-33.

14. Rogers CA, Angelini GD, Culliford LA, Capoun R, Ascione R. Coronary surgery in patients with preexisting chronic atrial fibrillation: early and midterm clinical outcome. Ann Thorac Surg. 2006;81:1676-82.

15. Bennett-Guerrero E, Zhao Y, O'Brien SM, Ferguson TB Jr, Peterson ED, Gammie JS, et al. Variation in use of blood transfusion in coronary artery bypass graft surgery. JAMA. 2010;304:1568-75.

16. Goodnough LT, Johnston MF, Toy PT. The variability of transfusion practice in coronary artery bypass surgery. Transfusion Medicine Academic Award Group. JAMA. 1991;265:86-90.

17. Ad N, Massimiano PS, Burton NA, Halpin L, Pritchard G, Shuman DJ, et al. Effect of patient age on blood product transfusion after cardiac surgery. $J$ Thorac Cardiovasc Surg. 2015;150:209-14.

18. Chen JH, Fang DZ, Goodnough LT, Evans KH, Lee Porter M, Shieh L. Why providers transfuse blood products outside recommended guidelines in spite of integrated electronic best practice alerts. J Hosp Med. 2015;10:1-7.

19. Ho D, Imai K, King G, Stuart E. Matching as nonparametric preprocessing for reducing model dependence in parametric causal inference. Polit Anal. 2007; 15:199-236.

20. Ho D, Imai K, King G, Stuart E. MatchIt: nonparametric preprocessing for parametric causal inference. J Stat Softw. 2011;42:1-28.
21. McMurry TL, Hu Y, Blackstone EH, Kozower BD. Propensity scores: methods, considerations, and applications in the Journal of Thoracic and Cardiovascular Surgery. J Thorac Cardiovasc Surg. 2015;150:14-9.

22. Karkouti K, Wijeysundera DN, Beattie WS, Reducing Bleeding in Cardiac Surgery (RBC) Investigators. Risk associated with preoperative anemia in cardiac surgery: a multicenter cohort study. Circulation. 2008;117:478-84.

23. Williams ML, He X, Rankin JS, Slaughter MS, Gammie JS. Preoperative hematocrit is a powerful predictor of adverse outcomes in coronary artery bypass graft surgery: a report from the Society of Thoracic Surgeons Adult Cardiac Surgery Database. Ann Thorac Surg. 2013;96:1628; discussion 1634.

24. Surgenor SD, DeFoe GR, Fillinger MP, Likosky DS, Groom RC, Clark C, et al. Intraoperative red blood cell transfusion during coronary artery bypass graft surgery increases the risk of postoperative low-output heart failure. Circulation. 2006;114(1 Suppl):I43-8.

25. Koch CG, Li L, Duncan AI, Mihaljevic T, Loop FD, Starr NJ, et al. Transfusion in coronary artery bypass grafting is associated with reduced long-term survival. Ann Thorac Surg. 2006;81:1650-7.

26. Kuduvalli M, Oo AY, Newall N, Grayson AD, Jackson M, Desmond MJ, et al. Effect of peri-operative red blood cell transfusion on 30-day and 1-year mortality following coronary artery bypass surgery. Eur J Cardiothorac Surg. 2005;27: 592-8.

27. Scott BH, Seifert FC, Grimson R. Blood transfusion is associated with increased resource utilisation, morbidity and mortality in cardiac surgery. Ann Card Anaesth. 2008;11:15-9.

28. LaPar DJ, Crosby IK, Ailawadi G, Ad N, Choi E, Spiess BD, et al. Blood product conservation is associated with improved outcomes and reduced costs after cardiac surgery. J Thorac Cardiovasc Surg. 2013;145:796; discussion 803-4.

29. Bracey AW, Radovancevic R, Riggs SA, Houston S, Cozart H, Vaughn WK, et al. Lowering the hemoglobin threshold for transfusion in coronary artery bypass procedures: effect on patient outcome. Transfusion. 1999;39:1070-7.

30. Santos AA, Silva JP, Silva LD, Sousa AG, Piotto RF, Baumgratz JF. Therapeutic options to minimize allogeneic blood transfusions and their adverse effects in cardiac surgery: a systematic review. Rev Bras Cir Cardiovasc. 2014; 29:606-21.

31. Holst LB, Haase N, Wetterslev J, Wernerman J, Guttormsen AB, Karlsson S, et al. Lower versus higher hemoglobin threshold for transfusion in septic shock. N Engl J Med. 2014;371:1381-91.

32. Hebert PC, Wells G, Blajchman MA, Marshall J, Martin C, Pagliarello G, et al. A multicenter, randomized, controlled clinical trial of transfusion requirements in critical care. Transfusion Requirements in Critical Care Investigators, Canadian Critical Care Trials Group. N Engl J Med. 1999;340:409-17.

33. Koch CG, Khandwala F, Li L, Estafanous FG, Loop FD, Blackstone EH. Persistent effect of red cell transfusion on health-related quality of life after cardiac surgery. Ann Thorac Surg. 2006;82:13-20.

34. Koch CG, Li L, Duncan AI, Mihaljevic T, Cosgrove DM, Loop FD, et al. Morbidity and mortality risk associated with red blood cell and bloodcomponent transfusion in isolated coronary artery bypass grafting. Crit Care Med. 2006;34:1608-16.

35. Yaffee DW, Smith DE III, Ursomanno PA, Hill FT, Galloway AC, DeAnda A, et al. Management of blood transfusion in aortic valve surgery: impact of a blood conservation strategy. Ann Thorac Surg. 2014;97:95-101.

36. Brown CH IV, Savage WJ, Masear CG, Walston JD, Tian J, Colantuoni E, et al. Odds of transfusion for older adults compared to younger adults undergoing surgery. Anesth Analg. 2014;118:1168-78.

Key Words: valve surgery, hemoglobin, anemia, outcomes

\section{Discussion}

Dr Glenn Whitman (Baltimore, Md). I want to thank the American Association for Thoracic Surgery (AATS) for allowing me this opportunity. I also want to thank Dr Ad for sending me his paper several months ago.

When the review committee for the AATS saw this abstract, every one of us was enthusiastic. This paper takes aim at all of us cardiovascular surgeons because we represent the primary group of transfusers in the world, yet we exhibit no standardized behavior. 
As much as I want to agree with the authors' conclusion that whether the discharge level of hemoglobin ( $\mathrm{Hbg})$ is $<8 \mathrm{~g} / \mathrm{dL}$ or $>8 \mathrm{~g} / \mathrm{dL}$ does not matter in valvular heart disease patients, I think we have to approach the conclusion with skepticism. Just recently, Dr Colleen Koch from the Cleveland Clinic published a paper on 153,000 discharged patients, without regard to diagnoses; utilizing the University HealthSystem Consortium, Inc, (UHC) database, she showed that in the group that had an Hbg level of $<9 \mathrm{~g} / \mathrm{dL}$, there was an almost 4-fold increase in readmissions at 30 days, compared with those female patients who had an Hbg level $>12 \mathrm{~g} / \mathrm{dL}$ and with male patients with an Hbg level $>13 \mathrm{~g} / \mathrm{dL}$. These findings were adjusted for confounding factors.

Furthermore, just last month, the Transfusion Indication Threshold Reduction study came out in the New England Journal of Medicine (Murphy GJ, Pike K, Rogers CA, Wordsworth S, Stokes EA, Angelini GD, et al. Liberal or restrictive transfusion after cardiac surgery. $N$ Engl J Med. 2015;372:997-1008). Seventeen institutions in England looked at all cardiac surgery patients, randomized them, 1000 in each group, to a triggered threshold of $9 \mathrm{~g} / \mathrm{dL}$ versus $7.5 \mathrm{~g} / \mathrm{dL}$ in the immediate postoperative period. When they looked at those discharged patientsin the transfusion trigger group of $9 \mathrm{~g} / \mathrm{dL}$, the Hbg level at discharge averaged $10 \mathrm{~g} / \mathrm{dL}$; in the trigger group of $7.5 \mathrm{~g} / \mathrm{dL}$, the Hbg level averaged $9 \mathrm{~g} / \mathrm{dL}$.

The investigators found no difference in their primary endpoint, which was ischemic or infection-related events at 90 days, including myocardial infarction, stroke, acute kidney injury, and gut infarctions. However, a secondary endpoint was 90-day mortality, which was lower in the group that was liberally transfused. In all fairness, though, comparing that study to this one is not entirely appropriate, as two thirds of that study population had coronary artery disease, whereas in the study presented today, none had coronary disease, because they were all isolated valve patients.

I have 2 questions that I want to raise with Dr Ad. One, what were, in fact, the $\mathrm{Hbg}$ concentrations in your 2 different populations? If there was very little difference in the Hbg concentrations, that might explain why the 2 groups behaved similarly.

The second question gets at the value of propensity matching. In all of the studies that are retrospective, nonrandomized, and utilize propensity matching, the quality of the study depends upon how well matched the 2 populations were. As an example, the fact that frailty, which we all understand is difficult to measure, is not included in these 2 populations might be viewed as a major drawback of the propensity matching. I think that not one of us, as disciplined as we might be, would sit at the foot of an extremely frail patient and withhold a transfusion if that patient were anemic.

The subjective assessment of frailty may have played a large role in who was permitted to be discharged with an
Hbg level $<8 \mathrm{~g} / \mathrm{dL}$. It must be acknowledged that, to the degree that frailty was not measured, and more-anemic patients were less frail, the conclusion that there is no difference in patients discharged with an Hbg level $<8 \mathrm{~g} /$ $\mathrm{dL}$ versus $>8 \mathrm{~g} / \mathrm{dL}$ may be incorrect.

Thank you.

Dr Niv Ad. Well, it was a long discussion, but I think you made some valid points. However, here is the point I am trying to make, and for those who work with me, this approach is very familiar. I want to raise a philosophical question, which is: Should we transfuse patients just because they are anemic, with no physiologic merit? I believe that the answer is no; and not all patients are the same.

Now, as far as our statistical method, I believe that it is important for you to understand what we did here. We did not base this study on a propensity-matched analysis only. We based this study on 2 very robust analyses: One is discharge Hgb level as a continuous variable; the other is a propensity match to supplement that, and it seems like you missed that.

No study is perfect, and it is very hard to randomize patients in multicenter studies in cardiac surgery in general, because the quality of the surgery is also important, and we do not talk about that. So, our study basically shows, with legitimate prospectively collected data, not a chart review, because we have a registered database, and data are being collected as we move on, that showed that, based on those 2 analyses, it is safe to discharge patients with low Hgb levels if they are asymptomatic.

Now, when we consider specific individual patients, then it is a question of individuality and variability, and this question probably should be answered with a more robust analysis of a subgroup of patients with lower Hgb level, different ages, frailty, renal failure, and so on. That was not the aim of our study. Our study was designed to answer one question, which is a philosophical question: Should we transfuse patients that are anemic just because they are anemic, even if their Hgb level is $<8 \mathrm{~g} / \mathrm{dL}$, and the answer is no.

Dr Whitman. Dr Ad-just for everybody's knowledge - what were the Hgb concentrations in these 2 groups?

Dr Ad. The average one?

Dr Whitman. Exactly.

Dr Ad. We clearly showed the average with a nice, simple figure; you probably missed it, because the distribution of $\mathrm{Hgb}$ level at discharge was demonstrated; 153 patients with an Hgb level $<8 \mathrm{~g} / \mathrm{dL}$, and about 70 patients with an $\mathrm{Hgb}$ level $<7 \mathrm{~g} / \mathrm{dL}$. The average for the entire group was $9.9 \mathrm{~g} / \mathrm{dL}$.

But I do not understand your point. The study points to the fact that, based on our 2 valid analyses, done by a superb statistician, Hgb level at discharge was not associated with a negative outcome.

Dr Whitman. Dr Ad, thank you. I was simply asking what the $\mathrm{Hgb}$ concentrations were in the 2 groups. 